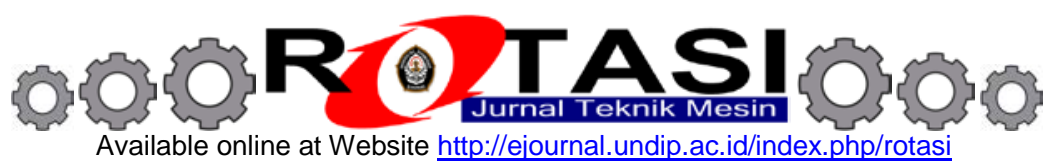

\title{
SIMULASI DISTRIBUSI TEMPERATUR DAN KELEMBABAN RELATIF RUANGAN DARI SISTEM DEHUMIDIFIKASI MENGGUNAKAN COMPUTATIONAL FLUIDS DYNAMICS (CFD)
}

\author{
*Eflita Yohana ${ }^{a}$, Bambang Yunianto ${ }^{a}$, Ade Eva Diana ${ }^{b}$ \\ ${ }^{a}$ Dosen Program Studi S1 Departemen Teknik Mesin, Fakultas Teknik, Universitas Diponegoro \\ ${ }^{\mathrm{b}}$ Mahasiswa Program Studi S1 Departemen Teknik Mesin, Fakultas Teknik, Universitas Diponegoro \\ Jl. Prof. Sudharto, SH., Tembalang-Semarang 50275, Telp. +62247460059 \\ *E-mail: efnan2003@gmail.com
}

\begin{abstract}
ABSTRAK
Dehumidifikasi merupakan proses pengurangan kadar uap air yang berpengaruh terhadap besar nilai kelembaban relatif dan temperatur suatu ruangan. Dalam mengkondisikan kadar uap air dalam suatu ruangan tersebut agar dapat sesuai dengan kebutuhan, maka perlu diketahui distribusi kelembaban relatif dan temperatur dalam ruangan menggunakan Computational Fluid Dynamics (CFD). Pada penelitian ini, pengambilan data dilakukan selama 20 menit dan dilakukan pada pukul 08.00 WIB. Liquid desiccant yang digunakan dijaga pada temperatur $10^{\circ} \mathrm{C}$ dengan variasi konsentrasi $40 \%$ dan 50\%. Sensor DHT 11 dipasang pada lima sisi, atap, dinding, lantai, inlet, outlet, yang berfungsi untuk mencatat perubahan kelembaban dan temperatur selama pengujian berlangsung. Pada kondisi normal tanpa menyalakan alat dehumidifier, sensor mencatat temperatur rata-rata di dalam ruangan sebesar 29,9 $9^{\circ} \mathrm{C}$ dan $\mathrm{RH} 58,9 \%$. Simulasi dilakukan menggunakan software CFD Solidworks Flow Simulation 2014. Validasi hasil eksperimen dengan hasil simulasi dengan membandingan bahwa liquid desiccant $40 \%$ dan $50 \%$, nozzle sprayer $0.2 \mathrm{~mm}$ dengan temperatur yang dijaga pada $10^{\circ} \mathrm{C}$ mempunyai distribusi yang cukup merata dengan konsentrasi $40 \%$ memiliki nilai RH terendah sebesar $65,21 \%$, nilai $\mathrm{RH}$ tertinggi sebesar $68,99 \%$, nilai $\omega=18 \mathrm{gr} / \mathrm{kg}$, serta mempunyai temperatur tertinggi $31,11^{\circ} \mathrm{C}$ dan temperatur terendah $30,05^{\circ} \mathrm{C}$. Sedangkan dengan konsentrasi $50 \%$ distribusi dalam ruangan juga cukup merata karena memiliki nilai RH terendah sebesar 59,21\%., nilai RH tertinggi sebesar $62,80 \%$, nilai $\omega$ $=17 \mathrm{gr} / \mathrm{kg}$, serta mempunyai temperatur tertinggi $31,71^{\circ} \mathrm{C}$ dan temperatur terendah $30,93^{\circ} \mathrm{C}$. Sehingga liquid desiccant dengan konsentrasi 50\% mempunyai nilai Humidity Ratio $(\omega)$ lebih rendah dibandingkan dengan yang memiliki konsentrasi $40 \%$.
\end{abstract}

Kata kunci: Dehumidifikasi, CFD, Liquid Desiccant $\mathrm{CaCl}_{2}$

\section{PENDAHULUAN}

Kelembaban merupakan jumlah uap air yang terkandung dalam udara. Berdasarkan fungsinya kelembaban berperan penting di bidang perkebunan dan pertanian karena menjadi faktor yang menunjang pertumbuhan tanaman. Dan juga sebaliknya, kelembaban yang berlebihan dapat menghambat pertumbuhan tanaman.

Kondisi kelembaban yang berlebihan dapat menyebabkan produktifitas kerja manusia cenderung menurun karena keadaan yang tidak nyaman seperti terlalu dingin atau terlalu panas. Suhu nyaman thermal untuk orang Indonesia berada pada rentang suhu $22,8^{\circ} \mathrm{C}-25,8^{\circ} \mathrm{C}$ dengan kelembaban $70 \%$ jika lebih dari itu dapat berdampak negatif pada kehidupan, karena jika derajat kelembaban udara (RH) diatas $70 \%$ maka bakteri dan mikroorganisme mudah berkembangbiak sehingga mengganggu kesehatan manusia [1]. 2

Sistem dehumidifikasi menjadi salah satu pilihan untuk menurunkan kelembaban suatu ruangan, karena lebih ekonomis dari segi daya listrik dan juga media sorbent yang digunakan murah dan tidak membahayakan lingkungan sekitar. Proses dehumidifikasi merupakan proses pengurangan uap air dalam aliran gas. Di dalam dehumidifier, desiccant disemprotkan ke dalam aliran udara yang mengandung uap air sehingga terjadi perpindahan massa dan panas sensibel. Udara mengalami dehumidifikasi secara adiabatis [2]. 5

Dalam penelitian ini dehumidifikasi menurunankan kelembaban udara yang terjadi di dalam sistem dehumidifier, dimana kelembaban udara (uap air) diserap oleh media penyerap (sorbent) berupa larutan Calcium Chloride $\left(\mathrm{CaCl}_{2}\right)$ dengan konsentrasi tertentu pada saat terjadi kontak dengan udara. Pada saat larutan sorbent terjadi kontak dengan udara, maka akan terjadi perpindahan massa uap air dari udara ke larutan akibat perbedaan tekanan parsial uap air. Proses ini mengakibatkan terjadinya penambahan kandungan $\mathrm{H}_{2} \mathrm{O}$ di larutan sorbent yang menyebabkan penurunan konsentrasi larutan $\mathrm{CaCl}_{2}$. Sehingga udara yang keluar melalui sistem dehumidifier berupa udara kering, dan larutan sorbent yang sudah berkontak dengan udara akan masuk ke regenerator. Regenerator digunakan untuk mengembalikan konsentrasi larutan $\mathrm{CaCl}_{2}$ agar dapat digunakan kembali pada dehumidifier. Siklus tersebut dapat dilihat pada Gambar $1.1[3]$. 


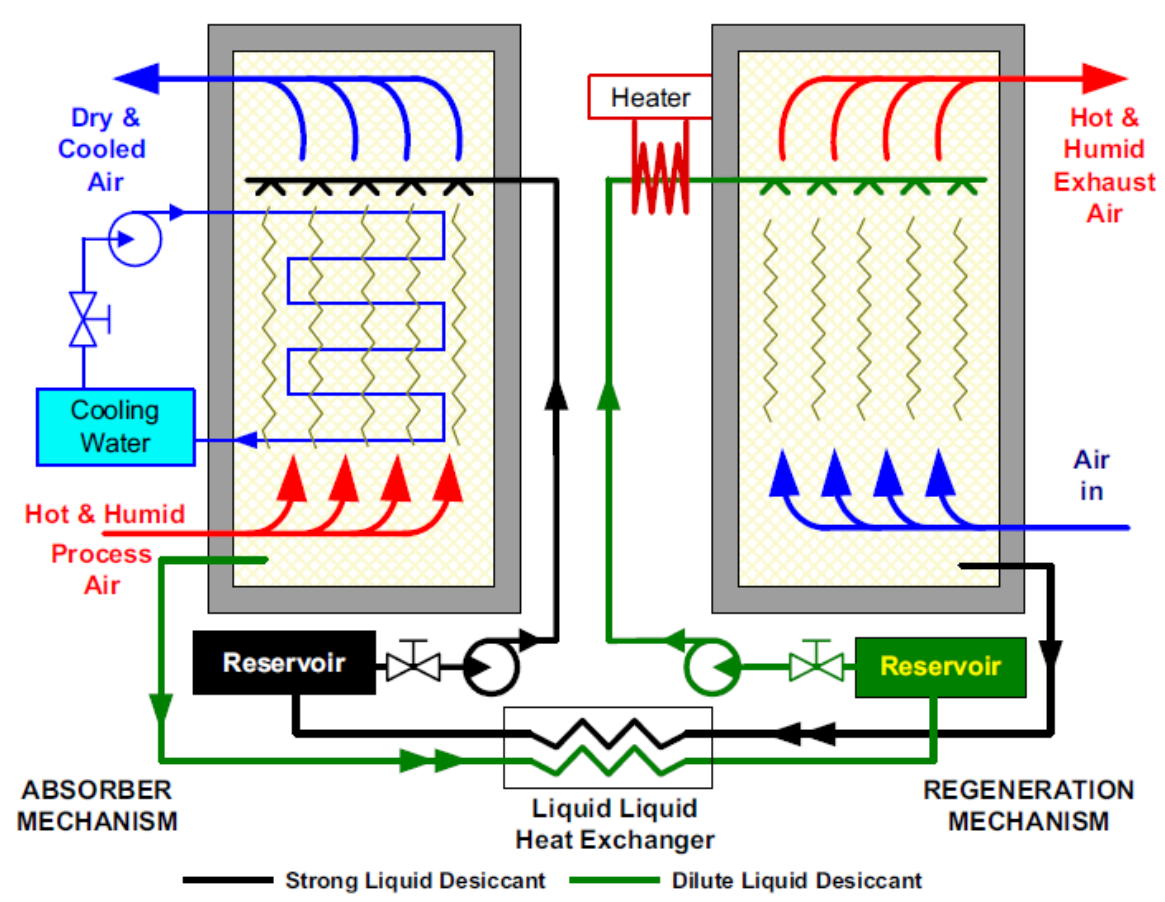

Gambar 1. Siklus dehumidifikasi pada dehumidifier.

Pada penelitian ini diperlukan simulasi numerik untuk mengetahui distribusi aliran khususnya distribusi suhu dan kelembaban yang tidak dapat dilihat secara langsung tanpa menggunakan alat-alat yang canggih seperti sensor suhu, sensor kelembaban dan kamera thermal. Untuk itulah, metode numerik merupakan salah satu solusi alternatif dalam analisis dinamika aliran (CFD) pada proses aliran fluida pada sample house. Metode numerik dapat memprediksi sesuatu dengan lebih cepat dan mudah serta biaya yang relatif lebih kecil dari eksperimental. Di samping itu metode numerik juga dapat mengatasi kendala geometri yang rumit dan syarat-syarat batas yang merupakan penghambat metode analitis. Kemudian akan dilakukan validasi dengan membandingkan hasil penelitian secara aktual dengan hasil simulasi.

\section{PERSAMAAN PEMBANGUN UNTUK ALIRAN FLUIDA}

Dalam fenomena suatu aliran fluida diperlukan beberapa persamaan - persamaan pembangun, diantaranya sebagai berikut.

\subsection{Hukum Kekekalan Momentum}

Hukum kedua Newton menyatakan bahwa laju perubahan momentum pada suatu partikel fluida sama dengan jumlah gaya-gaya yang bekerja pada partikel tersebut. Laju peningkatan momentum arah $\mathrm{x}$, y dan z per unit volume partikel fluida dituliskan dengan persamaan sebagai berikut:

$\rho \frac{D u}{D t}+\rho \frac{D v}{D t}+\rho \frac{D w}{D t}=0$

\subsection{Hukum Kekekalan Massa}

Keseimbangan massa pada suatu elemen fluida dapat dituliskan sebagai berikut:

"Laju pertambahan massa pada elemen fluida sama dengan netto laju aliran massa ke dalam elemen fluida tersebut" [4]. 8

$\frac{\partial}{\partial t}(\rho \delta x \delta y \delta z)=\frac{\partial \rho}{\partial t} \rho \delta x \delta y \delta z$

\subsection{Hukum Kekekalan Energi}

Persamaan energi diturunkan dari Hukum I Termodinamika yang berbunyi:

"Laju penambahan energi pada partikel fluida sama dengan laju penambahan panas pada partikel fluida ditambahkan dengan kerja yang terjadi pada partikel fluida tersebut”.

Persamaan energi tersebut dapat ditulis dalam bentuk sebagai berikut [5] : 9

$\frac{\partial(\rho E)}{\partial t}+\frac{\partial\left(u_{i}[\rho E+p]\right)}{\partial x_{i}}=\frac{\partial}{\partial x_{i}}\left(k_{e f f} \frac{\partial T}{\partial x_{i}}-\sum_{j} h_{j} J_{j}+u_{j}\left(\tau_{i j}\right)_{e f f}\right)+S_{h}$ 


\section{METODE PENELITIAN}

\subsection{Instalasi Alat Penelitian} berikut ini.

Dalam penelitian ini, penyusunan alat menjadi sebuah sistem instalasi penelitian ditampilkan pada Gambar 2

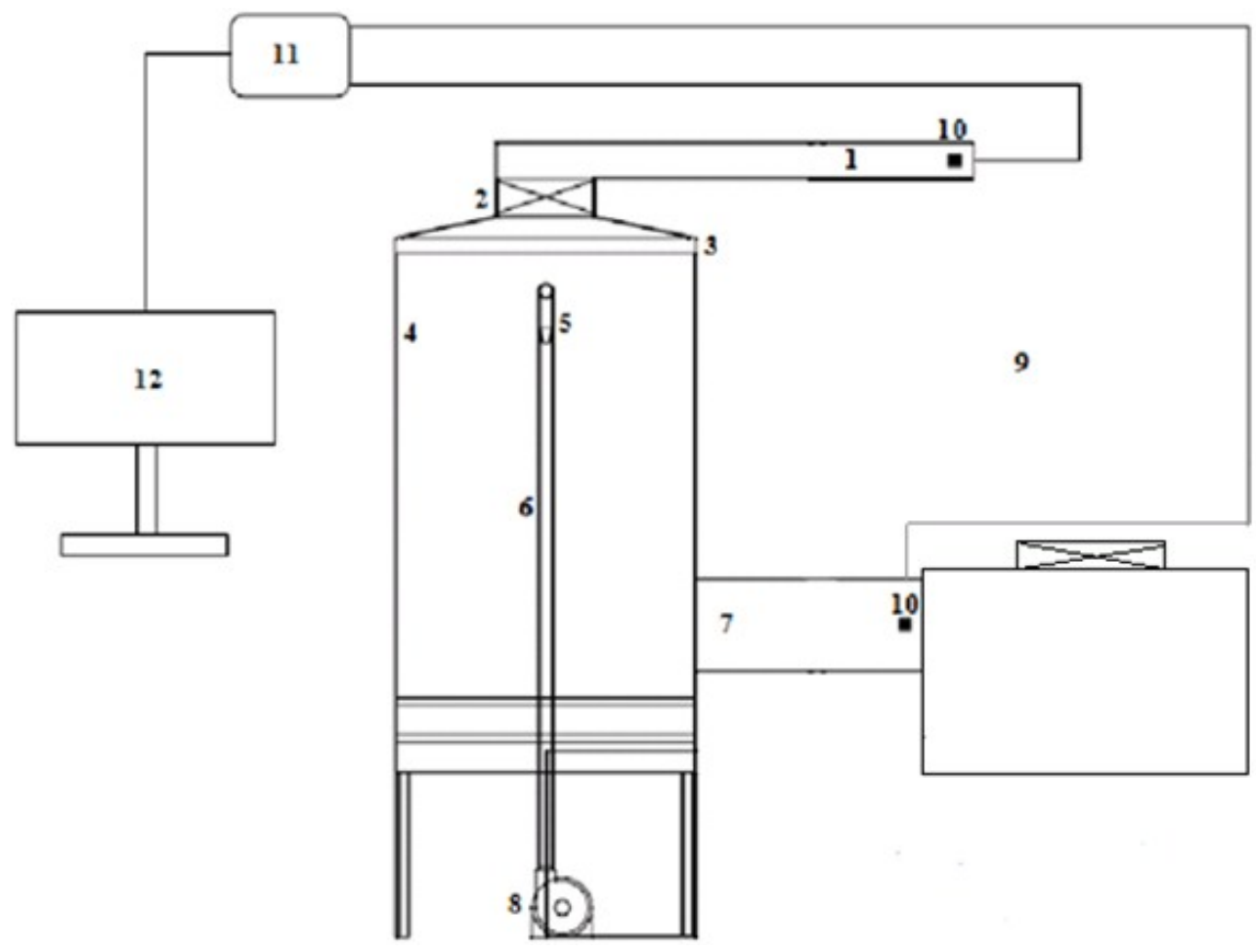

Gambar 2. Sistem instalasi penelitian.

dimana:

1. Saluran outlet humidifier

2. Fan

3. Eliminator

4. Ruangan Tower

5. Spraying Nozzle

6. Pipa saluran liquid desiccant

7. Saluran inlet humidifier

8. Pompa

9. Ruangan bebas

10. Sensor DHT 11

11. Micro controller

12. Laptop

13. Conditioing Box

Sample house memiliki dimensi 1,5 m x 1 m yang ditutup dengan menggunakan plastik, kemudian bagian inlet dan outlet dari dehumidifier tower dimasukkan ke dalam sample house tersebut. Dalam penelitian ini dehumidifier tower terbuat dari bahan acrylic dengan ketebalan $3 \mathrm{~mm}$. Pada Gambar 3 ditampilkan model geometri ruangan dehumidifikasi.

Penelitian dilakukan dengan memompa liquid desiccant $\mathrm{CaCl}_{2}$ dingin yang temperaturnya dijaga pada $10^{\circ} \mathrm{C}$ dari tangki penampung ke dehumidifier tower. Kemudian di dalam dehumidifier tower, larutan $\mathrm{CaCl}_{2}$ dengan konsentrasi 60\% akan didistribusikan menggunakan spraying nozzle dengan diameter 2 mm seperti yang terlihat pada Gambar 4. Perubahan kelembaban dan temperatur yang terjadi di dalam sample house akan diukur menggunakan sensor DHT 11 yang dipasang pada mulut inlet dan outlet dehumidifier tower selama 20 menit dengan waktu pengambilan data pada pukul 08.00 WIB. 


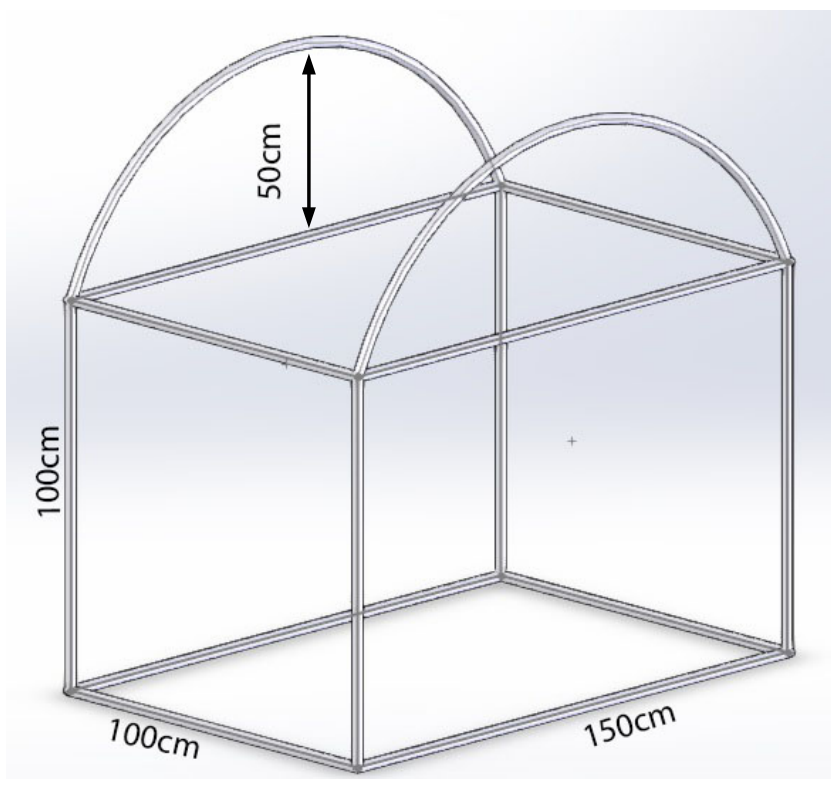

Gambar 3. Model geometri ruangan dehumidifikasi.

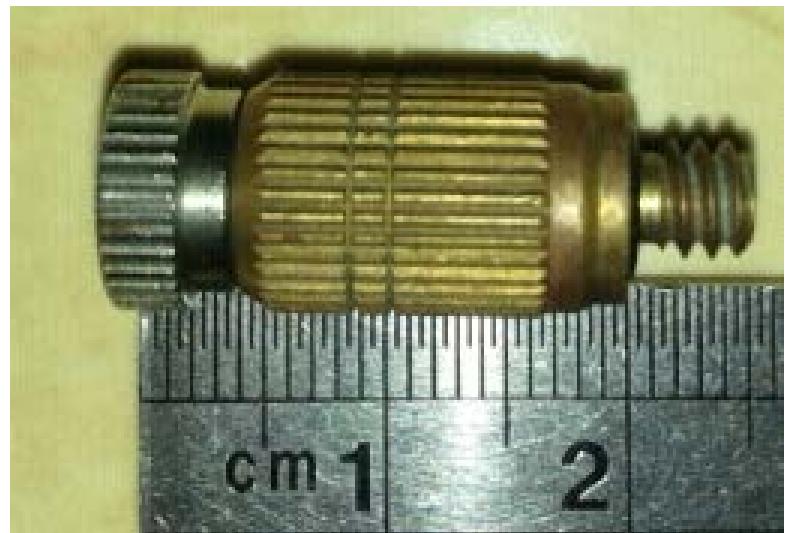

Gambar 4. Spraying nozzle dengan diameter $2 \mathrm{~mm}$ yang digunakan pada dehumidifier tower.

\subsection{Prosedur Penelitian}

Langkah-langkah dalam pengambilan data pada penelitian ini adalah sebagai berikut:

1. Mempersiapkan peralatan kemudian disusun sesuai gambar instalasi peralatan.

2. Mengisi tabung reservoir liquid desiccant dengan larutan $\mathrm{CaCl} 2$ yang memiliki konsentrasi $40 \%$ kemudian dipanaskan dan dijaga pada temperatur $10^{\circ} \mathrm{C}$.

3. Memasang nosel berukuran 0,2 mm pada humidifier.

4. Menghidupkan software LabView untuk pengambilan data berupa kelembaban udara serta temperatur udara.

5. Menyalakan pompa dan fan.

6. Menyalakan adaptor DC untuk thermoelectric dan fan heatsink di inlet humidifier hingga mencapai kondisi steady.

7. Melakukan pengambilan data selama 20 menit dan dicatat oleh software LabView. Pengambilan data dilakukan pada pukul 08.00 WIB.

8. Mengulangi langkah 2 sampai 6 dengan mengganti konsentrasi liquid desiccant menjadi 50\%.

9. Memvalidasi data penelitian dengan jurnal internasional.

10. Mengolah data kemudian dilakukan pembahasan dari data yang didapatkan.

11. Mengeplot data yang telah didapatkan.

12. Menarik kesimpulan.

\subsection{Diagram Alir Penelitian}

Untuk memudahkan dalam melakukan penelitian ini maka dibuat diagram alir penelitian seperti ditunjukkan pada Gambar 5 berikut. 
Eflita Yohana dkk., Simulasi Distribusi Temperatur Dan Kelembaban Relatif Ruangan Dari Sistem Dehumidifikasi Menggunakan Computational

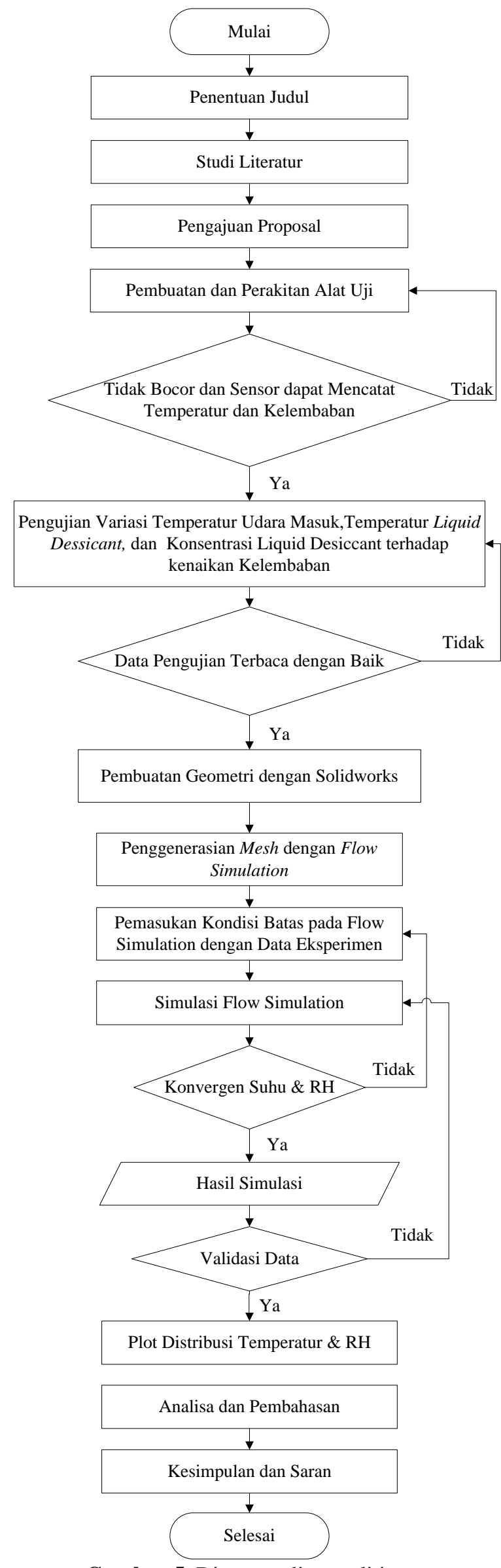

Gambar 5. Diagram alir penelitian. 
Eflita Yohana dkk., Simulasi Distribusi Temperatur Dan Kelembaban Relatif Ruangan Dari Sistem Dehumidifikasi Menggunakan Computational Fluids Dynamics (CFD)

\section{HASIL DAN PEMBAHASAN}

\subsection{Validasi Hasil Simulasi Kasus 1 dengan Jurnal Pendukung}

Kasus 1 disimulasikan dengan kondisi awal sesuai jurnal pendukung menggunakan software Solidworks 2014 Flow Simulation. Kondisi awal yang digunakan seperti yang terlihat pada Tabel 1 sedangkan hasilnya dapat dilihat pada Gambar 6, perbandingan garis isoline tidak terlalu berbeda jauh karena lekuk garis tersebut hampir menyerupai satu sama lain. Validasi suhu pada simulasi kasus 1 dengan jurnal pendukung dapat dilihat pada Tabel 2.

Tabel 1. Parameter dan Boundary Condition dari jurnal pendukung

\begin{tabular}{cc}
\hline Parameter & Boundary Condition \\
\hline Suhu Masuk & $289.2 \mathrm{~K}$ \\
Cover & LLDPE \\
Thickness & $0.1 \mathrm{~mm}$ \\
Caves Height & $2.4 \mathrm{~m}$ \\
Total Height & $4.1 \mathrm{~m}$ \\
Total Width & $8 \mathrm{~m}$ \\
Total Length & $20 \mathrm{~m}$ \\
Vents Located & $0.65 \mathrm{~m}$ above the ground \\
Maximum opening Vents & $15 \mathrm{~m}$ length x 0.9m height
\end{tabular}

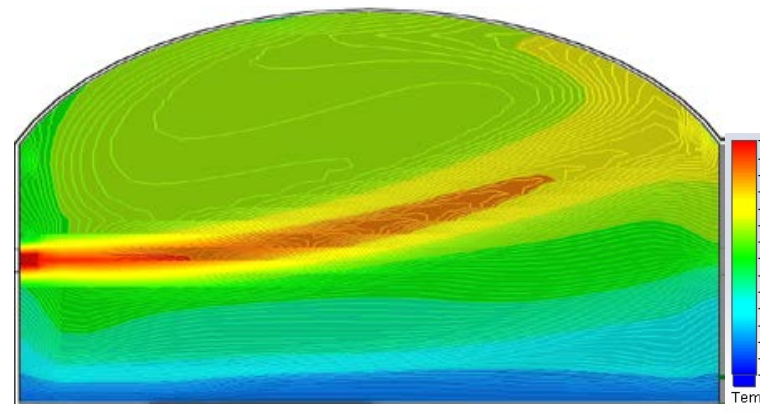

(a)

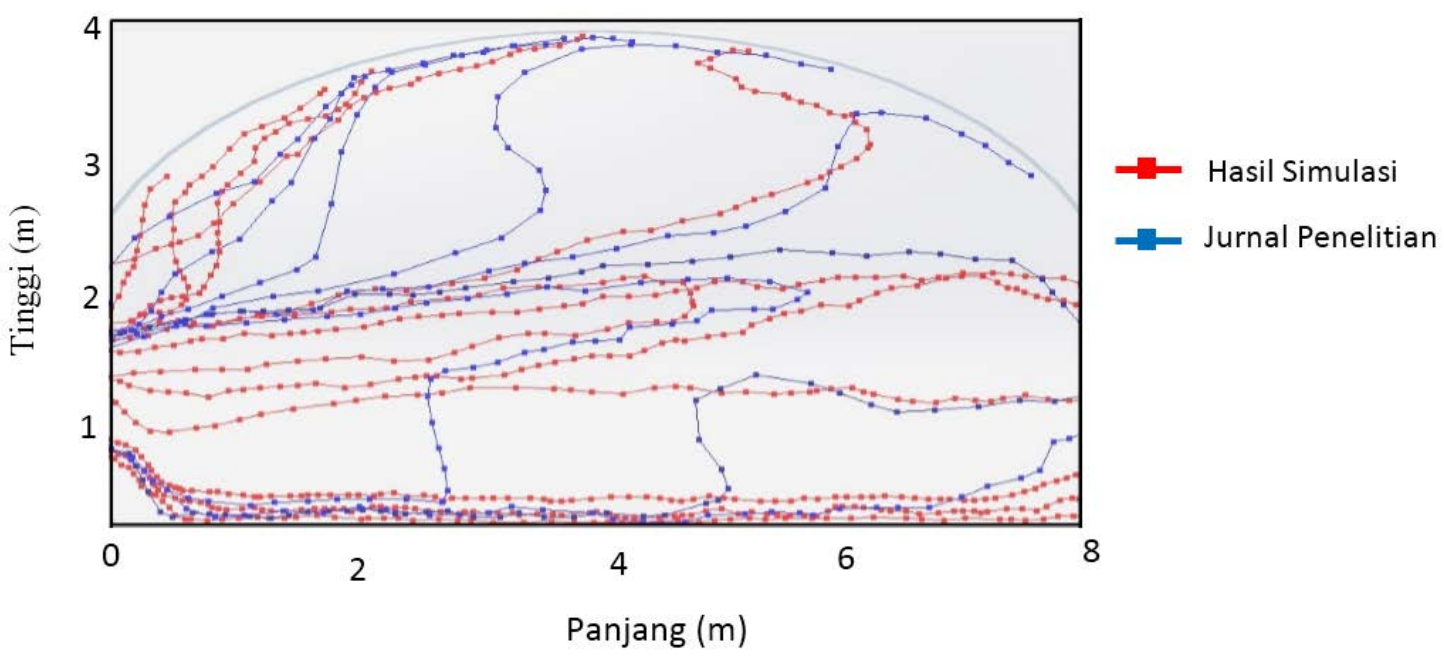

(c)

Gambar 6. Perbandingan garis isoline temperatur sample house hasil simulasi dengan greenhouse pada paper Catherine Baxevanou ${ }^{[14]}$ (a) Hasil Simulasi Kasus 1, (b) Jurnal Penelitian, (c) Perbandingan Isoline menggunakan software Data Graph.

Tabel 2. Validasi suhu pada simulasi kasus 1 dengan jurnal pendukung.

\begin{tabular}{lcccc}
\hline \multicolumn{1}{c}{ Suhu (K) } & Simulasi & Eksperimen & Beda & Eror \\
\hline Maksimal & 295 & 293.20 & 1.80 & $0.6 \%$ \\
Minimum & 289 & 288.20 & 0.80 & $0.3 \%$ \\
\hline
\end{tabular}




\subsection{Analisa Hasil Simulasi Kasus 2}

Pada kasus 2 ini simulasi CFD dilakukan untuk mengetahui distribusi temperatur udara dan relative humidity (RH) di dalam ruang dehumidifikasi. Liquid desiccant yang digunakan adalah $\mathrm{CaCl}_{2}$ konsentrasi $40 \%$ dengan temperatur $10^{\circ} \mathrm{C}$. Nosel yang digunakan berdiameter $0,2 \mathrm{~mm}$ dengan waktu pengambilan data pukul 08.00 WIB.

Pada Gambar 7 ditampilkan kontur temperatur yang menjelaskan bahwa distribusi temperatur di dalam ruangan cukup merata yaitu berkisar pada $30,5^{\circ} \mathrm{C}$, dan temperatur paling tinggi berada pada inlet sebesar $31,11^{\circ} \mathrm{C}$. Validasi untuk suhu antara eksperimen dan simulasi pada kasus ini ditunjukkan pada Tabel 3.

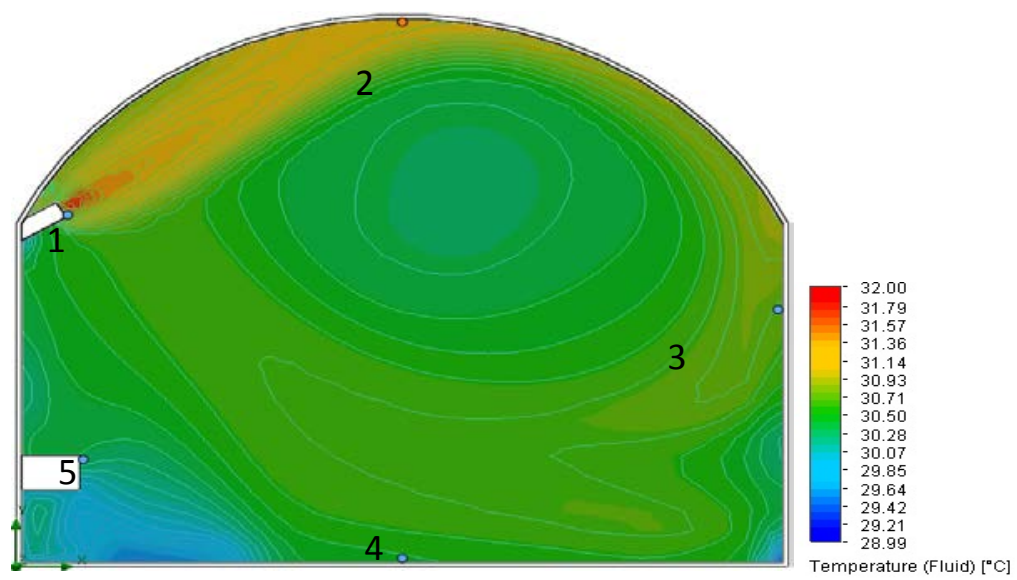

Gambar 7. Kontur temperatur pada kasus 2.

Tabel 3. Validasi suhu antara eksperimen dan simulasi pada kasus 2.

\begin{tabular}{cccccccc}
\hline \multirow{2}{*}{ Sensor } & \multicolumn{3}{c}{ Titik } & \multicolumn{5}{c}{ Suhu $\left({ }^{\circ} \mathrm{C}\right)$} \\
\cline { 2 - 8 } & $\mathrm{X}(\mathrm{m})$ & $\mathrm{Y}(\mathrm{m})$ & $\mathrm{Z}(\mathrm{m})$ & Simulasi & Eksperimen & Beda & Eror \\
\hline 1 & 0.2 & 1.22 & 0.5 & 31.11 & 31 & 0.11 & $0,4 \%$ \\
2 & 0.75 & 1.47 & 0.5 & 30.57 & 29 & 1.57 & $5 \%$ \\
3 & 1.48 & 0.82 & 0.5 & 30.14 & 29 & 1.14 & $4 \%$ \\
4 & 0.75 & 0.02 & 0.5 & 30.26 & 28 & 2.26 & $8 \%$ \\
5 & 0.23 & 0.45 & 0.5 & 29.99 & 29 & 0.99 & $3 \%$ \\
\hline
\end{tabular}

Gambar 8 menunjukkan bahwa distribusi RH di dalam ruangan berkisar antara 68,99\%, dan RH paling rendah berada pada sisi inlet sebesar 65,21\%. Sedangkan Tabel 4 menunjukkan validasi RH antara eksperimen dan simulasi. Untuk mengetahui keakuratan model CFD yang dibuat maka dilakukan validasi nilai RH hasil simulasi dengan hasil pengukuran dari eksperimen yang telah dilakukan.

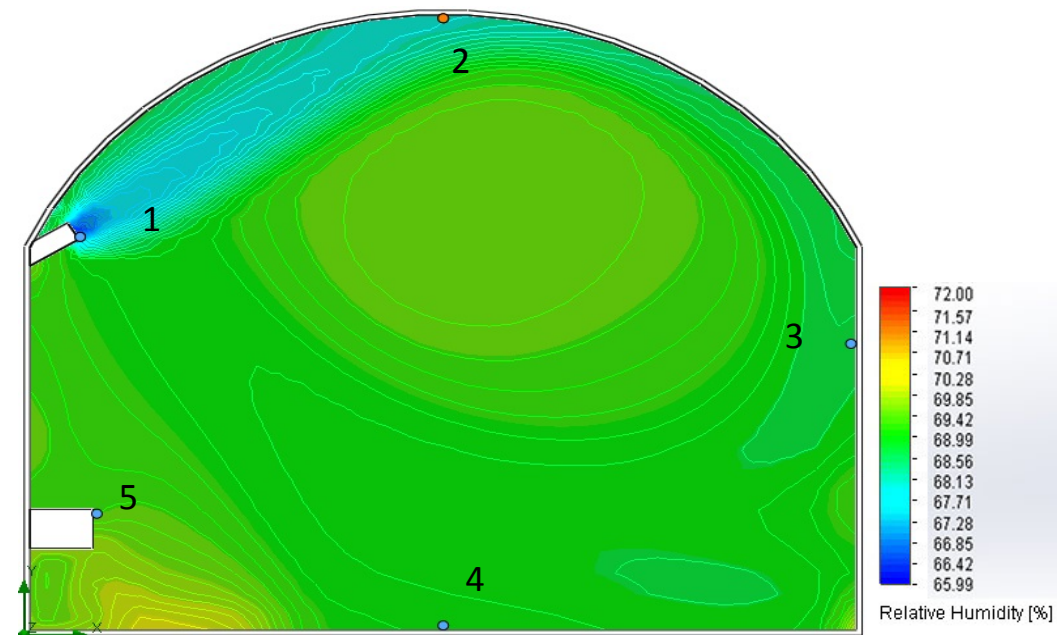

Gambar 8. Kontur RH pada kasus 2. 
Eflita Yohana dkk., Simulasi Distribusi Temperatur Dan Kelembaban Relatif Ruangan Dari Sistem Dehumidifikasi Menggunakan Computational Fluids Dynamics (CFD)

Tabel 4. Validasi Relative Humidty antara eksperimen dan simulasi pada kasus 2.

\begin{tabular}{|c|c|c|c|c|c|c|c|}
\hline \multirow{2}{*}{ Sensor } & \multicolumn{3}{|c|}{ Titik } & \multicolumn{4}{|c|}{ RH (\%) } \\
\hline & $\mathrm{X}(\mathrm{m})$ & $\mathrm{Y}(\mathrm{m})$ & $\mathrm{Z}(\mathrm{m})$ & Simulasi & Eksperimen & Beda & Eror \\
\hline 1 & 0.2 & 1.22 & 0.5 & 65.21 & 65 & 0.21 & $0.3 \%$ \\
\hline 2 & 0.75 & 1.47 & 0.5 & 67.93 & 67 & 0,93 & $1 \%$ \\
\hline 3 & 1.48 & 0.82 & 0.5 & 68.98 & 67 & 1.98 & $3 \%$ \\
\hline 4 & 0.75 & 0.02 & 0.5 & 69.29 & 71 & 1.71 & $2 \%$ \\
\hline 5 & 0.23 & 0.45 & 0.5 & 70.59 & 70 & 0.6 & $1 \%$ \\
\hline
\end{tabular}

\subsection{Analisa Hasil Simulasi Kasus 3}

Pada kasus 3 ini simulasi CFD dilakukan untuk mengetahui distribusi temperatur udara dan relative humidity (RH) di dalam ruang dehumidifikasi. Liquid desiccant yang digunakan adalah $\mathrm{CaCl}_{2}$ konsentrasi $50 \%$ dengan temperatur $10^{\circ} \mathrm{C}$. Nosel yang digunakan berdiameter $0,2 \mathrm{~mm}$ dengan waktu pengambilan data pukul 08.00 WIB.

Pada Gambar 9 ditampilkan kontur temperatur yang menjelaskan bahwa distribusi temperatur di dalam ruangan cukup merata yaitu berkisar pada $30,93^{\circ} \mathrm{C}$, dan temperatur paling tinggi berada pada inlet sebesar $31,71^{\circ} \mathrm{C}$. Validasi untuk suhu antara eksperimen dan simulasi pada kasus ini ditunjukkan pada Tabel 5.

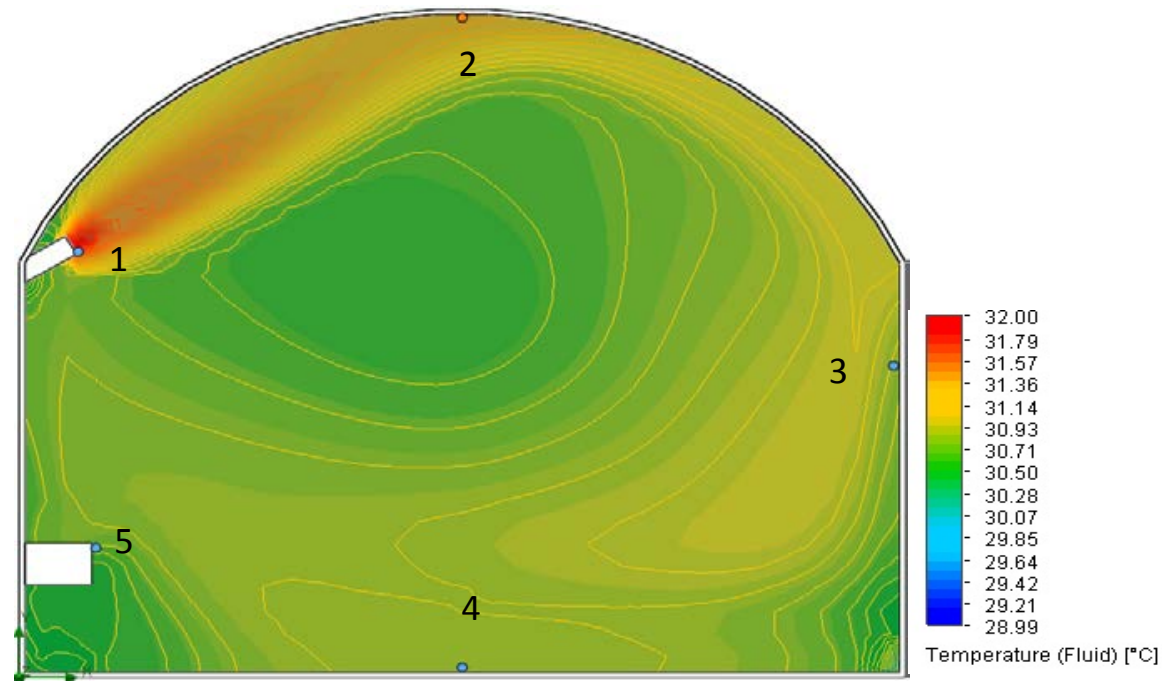

Gambar 9. Kontur temperatur pada kasus 3.

Tabel 5. Validasi suhu antara eksperimen dan simulasi pada kasus 3.

\begin{tabular}{|c|c|c|c|c|c|c|c|}
\hline \multirow{2}{*}{ Sensor } & \multicolumn{3}{|c|}{ Titik } & \multicolumn{4}{|c|}{ Suhu $\left({ }^{\circ} \mathrm{C}\right)$} \\
\hline & $X(m)$ & $\mathrm{Y}(\mathrm{m})$ & $\mathrm{Z}(\mathrm{m})$ & Simulasi & Eksperimen & Beda & Eror \\
\hline 1 & 0.2 & 1.22 & 0.5 & 31,71 & 31 & 0,71 & $2 \%$ \\
\hline 2 & 0.75 & 1.47 & 0.5 & 31,32 & 30 & 1,32 & $4 \%$ \\
\hline 3 & 1.48 & 0.82 & 0.5 & 30,90 & 30 & 0.9 & $3 \%$ \\
\hline 4 & 0.75 & 0.02 & 0.5 & 30,72 & 28 & 2,72 & $10 \%$ \\
\hline 5 & 0.23 & 0.45 & 0.5 & 30,58 & 29 & 1,58 & $5 \%$ \\
\hline
\end{tabular}

Gambar 10 menunjukkan bahwa distribusi RH di dalam ruangan berkisar antara 62,80\%, dan RH paling rendah berada pada sisi inlet sebesar 59,21\%. Sedangkan Tabel 6 menunjukkan validasi RH antara eksperimen dan simulasi. Untuk mengetahui keakuratan model CFD yang dibuat maka dilakukan validasi nilai RH hasil simulasi dengan hasil pengukuran dari eksperimen yang telah dilakukan. 


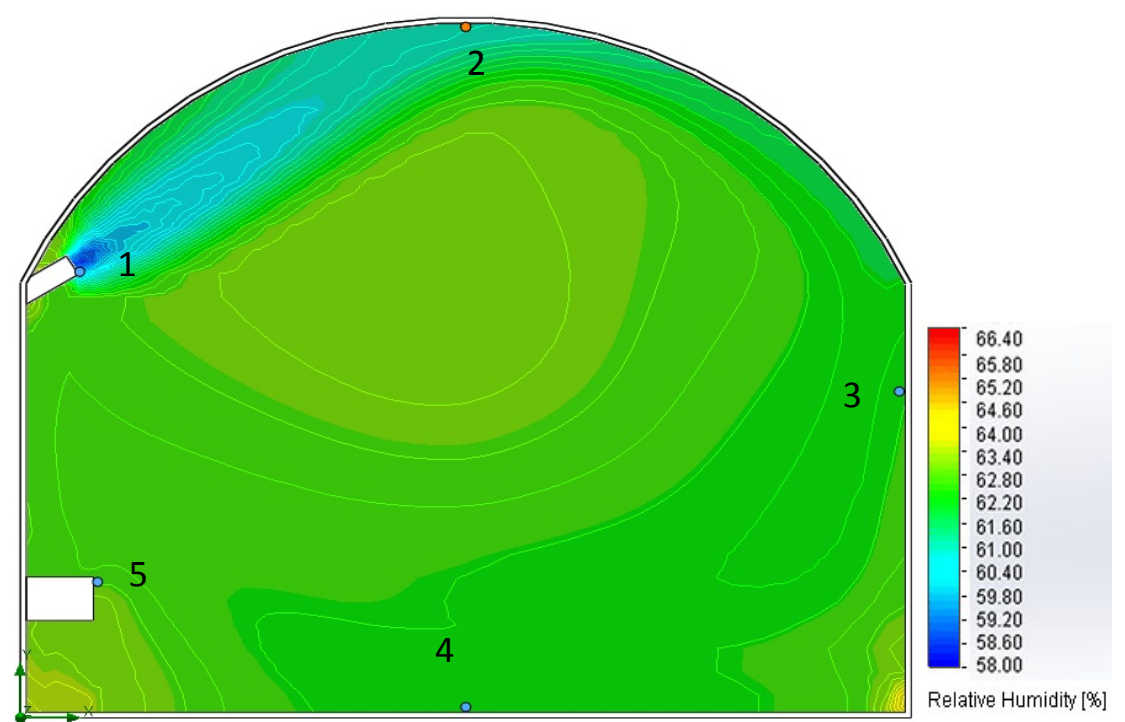

Gambar 10. Kontur RH pada kasus 3.

Tabel 6. Validasi Relative Humidty antara eksperimen dan simulasi pada kasus 2.

\begin{tabular}{|c|c|c|c|c|c|c|c|}
\hline \multirow{2}{*}{ Sensor } & \multicolumn{3}{|c|}{ Titik } & \multicolumn{4}{|c|}{ RH (\%) } \\
\hline & $\mathrm{X}(\mathrm{m})$ & $\mathrm{Y}(\mathrm{m})$ & $\mathrm{Z}(\mathrm{m})$ & Simulasi & Eksperimen & Beda & Eror \\
\hline 1 & 0.2 & 1.22 & 0.5 & 59,21 & 59 & 0.2 & $0.3 \%$ \\
\hline 2 & 0.75 & 1.47 & 0.5 & 60.68 & 59 & 1.68 & $3 \%$ \\
\hline 3 & 1.48 & 0.82 & 0.5 & 62.42 & 61 & 1.42 & $2 \%$ \\
\hline 4 & 0.75 & 0.02 & 0.5 & 63.12 & 64 & 0.9 & $1 \%$ \\
\hline 5 & 0.23 & 0.45 & 0.5 & 63.72 & 62 & 1.72 & $3 \%$ \\
\hline
\end{tabular}

Berdasarkan kontur RH, dapat dianalisis bahwa dengan konsentrasi liquid desiccant 40\% dan 50\% dengan diameter nozzle $0,2 \mathrm{~mm}$, temperatur liquid desiccant $10^{\circ} \mathrm{C}$ serta dengan waktu pengambilan data pukul $08.00 \mathrm{WIB}$, mengalami kenaikan temperatur sebesar $2^{\circ} \mathrm{C}$, serta terjadi penurunan $\mathrm{RH}$ sebesar $8 \%$ di dalam ruangan. Pada kasus 3 ini kelembaban yang dicapai cukup rendah sehingga proses transfer massa dalam tower dehumidifier cukup optimal dalam menyerap kandungan udara. Terjadinya perpindahan massa uap air dari udara ke liquid desiccant dan perpindahan massa di dalam tower dehumidifier menyebabkan partikel-partikel di dalam udara saling bergesekan sehingga membuat temperatur udara meningkat.

Pada kasus 3 ini dapat diketahui nilai humidity ratio $(\omega)$ pada masing - masing titik dengan menggunakan software COOLERADO HDPsyChart. Seperti yang ditunjukkan pada Tabel 7 berikut ini bahwa kasus ini mempunyai nilai Humidity Ratio $(\omega)$ yang rendah.

Tabel 7. Nilai Humidity Ratio Kasus 2

\begin{tabular}{ccccc}
\hline \multirow{2}{*}{ Sensor } & \multicolumn{3}{c}{ Titik } \\
\cline { 2 - 5 } & $\mathrm{X}(\mathrm{m})$ & $\mathrm{Y}(\mathrm{m})$ & $\mathrm{Z}(\mathrm{m})$ & $\omega(\mathrm{gr} / \mathrm{kg})$ \\
\hline 1 & 0.20 & 1.22 & 0.50 & 18.74 \\
2 & 0.75 & 1.47 & 0.50 & 18.93 \\
3 & 1.48 & 0.82 & 0.50 & 18.95 \\
4 & 0.75 & 0.02 & 0.50 & 18.97 \\
5 & 0.23 & 0.45 & 0.50 & 19.03 \\
\hline
\end{tabular}


Eflita Yohana dkk., Simulasi Distribusi Temperatur Dan Kelembaban Relatif Ruangan Dari Sistem Dehumidifikasi Menggunakan Computational

Fluids Dynamics (CFD)

Tabel 8. Nilai Humidity Ratio Kasus 3

\begin{tabular}{ccccc}
\hline \multirow{2}{*}{ Sensor } & \multicolumn{3}{c}{ Titik } \\
\cline { 2 - 5 } & $\mathrm{X}(\mathrm{m})$ & $\mathrm{Y}(\mathrm{m})$ & $\mathrm{Z}(\mathrm{m})$ & $\omega(\mathrm{gr} / \mathrm{kg})$ \\
\hline 1 & 0.20 & 1.22 & 0.50 & 17.56 \\
2 & 0.75 & 1.47 & 0.50 & 17.59 \\
3 & 1.48 & 0.82 & 0.50 & 17.63 \\
4 & 0.75 & 0.02 & 0.50 & 17.68 \\
5 & 0.23 & 0.45 & 0.50 & 17.73 \\
\hline
\end{tabular}

Dari kedua tabel diatas dapat dilihat bahwa kasus 3 mempunyai nilai Humidity Ratio ( $\omega$ ) paling rendah dibandingkan dengan kasus 2. Berdasarkan hasil analisa dari kasus 2 dan 3, terlihat adanya distribusi baik temperatur maupun kelembaban relatif udara di dalam ruangan. Gambar 9 memperlihatkan hasil simulasi aliran udara melalui inlet hingga terdistribusi di dalam ruangan.
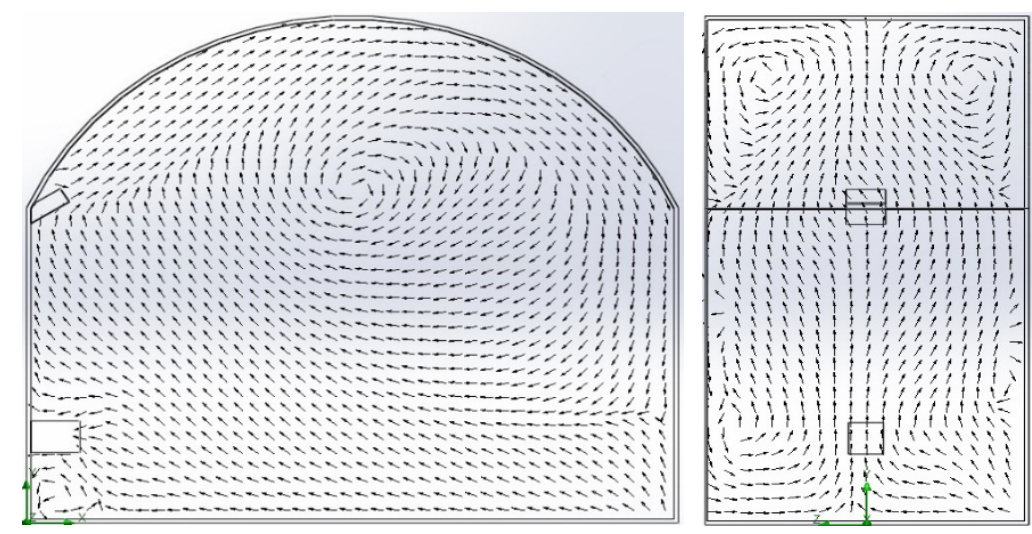

Gambar 11. Distribusi aliran udara di dalam ruangan.

Gambar 11 memperlihatkan bahwa desain ruangan dan letak inlet dalam ruangan mempengaruhi distribusi aliran udara di dalam ruangan. Udara yang mengalir dari inlet dinggap uniform bergerak lurus menjauh dari inlet hingga mencapai ujung ruangan. Selanjutnya udara akan tersebar mengikuti bentuk ruangan tersebut. Desain ini merupakan penyempurnaan dari penelitian sebelumnya. Dengan bentuk ruangan seperti Gambar 12 berikut ini yang diambil dari jurnal "The Simulation of Temperature Distribution and Relative Humidity with Liquid Dessicant Concentration of 50\% Using Computational Fluid Dynamics” [15].
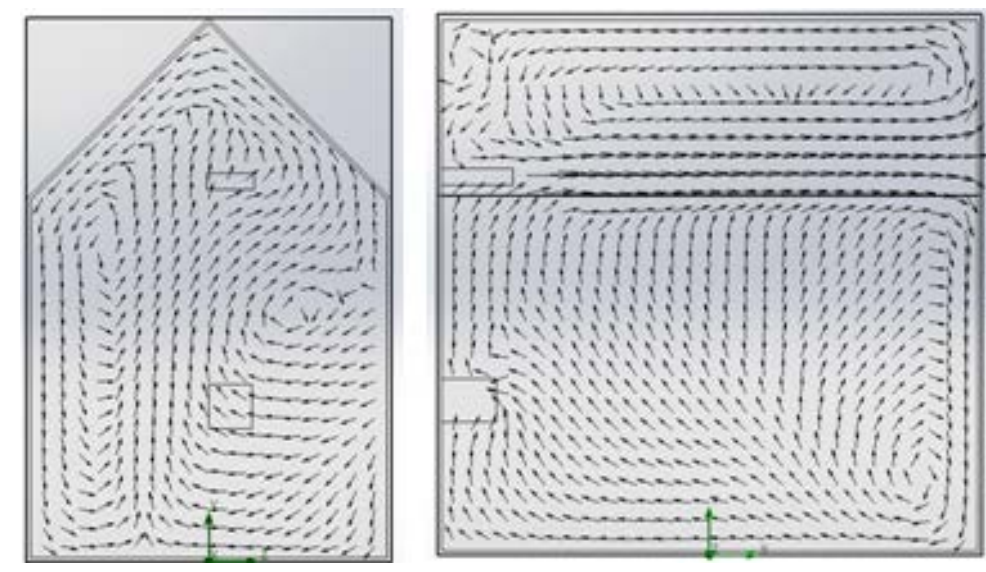

Gambar 12. Distribusi aliran udara jurnal [15].

\section{KESIMPULAN}

Jika melihat hasil simulasi CFD kedua kasus dapat disimpulkan bahwa pada kasus 1 distribusi di dalam ruangan dengan memvalidasikan simulasi dan jurnal menunjukkan kemiripan garis isoline. Dengan nilai eror suhu maksimal sebesar 0,6\% dan suhu minimal sebesar 0,3\%. Pada kasus 2 kondisi udara di dalam ruangan dengan menyalakan alat 
dehumidifier menggunakan konsentrasi liquid dessicant sebesar 40\%, mempunyai nilai RH terendah pada inlet 62,21\%, nilai RH tertinggi pada outlet 70,59\%, dengan nilai $\omega=18 \mathrm{gr} / \mathrm{kg}$, serta mempunyai temperatur tertinggi pada outlet $31,11^{\circ} \mathrm{C}$, temperatur terendah pada outlet $29,99^{\circ} \mathrm{C}$. Sedangkan pada kasus 3 alat dehumidifier menggunakan konsentrasi liquid dessicant sebesar 50\%, mempunyai nilai RH terendah pada inlet 59,21\%, nilai RH tertinggi pada outlet $63,72 \%$ dengan nilai $\omega=17 \mathrm{gr} / \mathrm{kg}$, serta mempunyai temperatur tertinggi pada outlet $31,71^{\circ} \mathrm{C}$, temperatur terendah pada outlet $30,58^{\circ} \mathrm{C}$. Hasil simulasi yang dilakukan dari ketiga kasus ini menunjukkan bahwa semakin besar konsentrasi liquid desiccant, maka semakin besar kemampuan untuk menurunkan kelembaban di dalam ruangan. Sehingga temperatur dan kelembaban dalam ruangan dapat tersebar merata.

\section{DAFTAR PUSTAKA}

[1] Lippsmeier, G., 1994, “Tropenbau Building in the Tropics,” Bangunan Tropis (terj.), Jakarta: Erlangga.

[2] Maryadi, D., 2009. Simulasi Pengaruh Parameter (Kecepatan dan Temperatur) Udara dan Desiccant terhadap Laju Perubahan Humidifikasi dalam Regenerator Menggunakan CFD. Semarang: Tugas Akhir Teknik Mesin Universitas Diponegoro.

[3] Treybal, R.E., 1980, “Mass-Transfer Operations,” McGraw-Hill International Edition. Third Edition.

[4] Versteeg, H.K., Malalasakera, W., 1995, “An Introduction to Computational Fluid Dynamic,” Longman Scientific \& Technical, England.

[5] Fahmi, N.M., 2013, "Simulasi Distribusi Suhu dan Kelembaban Relatif Pada Rumah Tanaman (Green House) Dengan Sistem Humidifikasi,” Semarang: Tugas Akhir Teknik Mesin Universitas Diponegoro. 